\title{
Comparison between lambs and goat kids meat production of animals fed Caatinga vegetation enriched with buffel (Cenchrus ciliaris L.) grass
}

\section{Comparação entre a produção de carne de cordeiros e cabritos alimentados em vegetação nativa de Caatinga enriquecida com capim-buffel (Cenchrus ciliaris L.)}

\author{
Nadjanara Souza Oliveira Mota ${ }^{1}$; José Morais Pereira Filho²; Luiza Daiana Araújo \\ da Silva Formiga ${ }^{1}$; Aderbal Marcos de Azevêdo Silva²; Marcílio Fontes Cezar²; \\ Olaf Andreas Bakke²; Jucileide Barboza Borburema ${ }^{1}$; Ronaldo Lopes Oliveira ${ }^{3}$; \\ Leilson Rocha Bezerra ${ }^{2 *}$
}

\begin{abstract}
This study compared the performance and meat production of goat kids and lambs that were fed semiarid Caatinga vegetation enriched with buffel grass (Cenchrus ciliaris L.). Twelve crossbred Boer $\times$ undefined breed goat kids and 12 Santa Inês lambs that had $20.7 \mathrm{~kg}$ of body weight (BW) were studied. Goat kids presented greater $(P<0.05)$ organic matter intake and digestibility, total gain, average daily gain (ADG) and perirrenal fat compared to lambs fed Caatinga vegetation enriched with buffel grass. However, the morphometric carcass measurements (external and leg length; chest and rump width; leg perimeter and chest circumference) were higher $(P<0.05)$ in lambs compared to those of goat kids. The crude protein and neutral detergent fiber intake and digestibility, cooling carcass loss, biological yield, empty body weight, hot carcass and cold carcass weights and yields, subcutaneous fat thickness, carcass compactness index and Longissimus dorsi area were similar $(P>0.05)$ between goat kids and lambs. Goat kids (crossbred Boer $\times$ undefined breed) more efficiently used Caatinga vegetation enriched with Cenchrus ciliaris L. than Santa Inês lambs; this vegetation improved nutrient intake, ADG and, consequently, feeding conversion. However, Santa Inês lambs presented higher carcass morphometric values.
\end{abstract}

Key words: Cenchrus ciliaris L. Drought. Longissimus dorsi area. Ruminant. Semi-arid.

\section{Resumo}

Este estudo comparou o desempenho e a produção de carne de cabritos e cordeiros alimentados com Caatinga enriquecida com capim-buffel (Cenchrus ciliaris L.) na região semiárida. Doze cabritos mestiços Boer $\times$ sem padrão racial definido (SRD) e 12 cordeiros Santa Inês foram utilizados pesando

\footnotetext{
1 Discentes de Mestrado em Ciência Animal, Centro de Saúde e Tecnologia Rural da Universidade Federal de Campina Grande, Patos, PB, Brasil. E-mail: narinhavet@hotmail.com; luizadaiana@hotmail.com; jucileidebarboza@hotmail.com

2 Profs., Unidade Acadêmica de Medicina Veterinária, UAMV e Engenharia Florestal, UAEF, Centro de Saúde e Tecnologia Rural da Universidade Federal de Campina Grande, Patos, PB, Brasil. E-mail: jmorais@cstr.ufcg.edu.br; silvaama@gmail.com; mfcezar@gmail.com; obakke@cstr.ufcg.edu.br; leilson@ufpi.edu.br

3 Prof., Departamento de Zootecnia, Faculdade de Medicina Veterinária e Zootecnia/Universidade Federal da Bahia, Salvador, BA, Brasil. E-mail: ronaldooliveira@ufba.edu.br

* Author for correspondence
} 
em média de 20,7 $\mathrm{kg}$ de peso vivo (PV). Os cabritos apresentaram maior $(P<0,05)$ consumo e digestibilidade de matéria orgânica, ganho de peso total, ganho de peso médio diário (GPMD) e gordura perirrenal em relação aos cordeiros alimentados em Caatinga enriquecida com capim-buffel. Porém, as medidas morfométricas da carcaça (comprimento do peito e da perna, largura do peito e da anca, perímetro da perna e circunferência do peito) foram maiores $(P<0,05)$ nos cordeiros quando comparados aos cabritos. O consumo e a digestibilidade da proteína bruta e da fibra em detergente neutro, perda de carcaça por resfriamento, rendimento biológico, peso do corpo vazio, peso e rendimento das carcaças quente e fria, gordura subcutânea, índice de compactação da carcaça e área de Longissimus dorsi foram semelhantes $(P>0,05)$ entre cabritos e cordeiros. Cabritos (cruzamento Boer $\times \mathrm{SRD})$ utilizam mais eficientemente a vegetação de Caatinga enriquecida com Cenchrus ciliaris L. que os cordeiros Santa Inês, melhorando a ingestão de nutrientes, GPMD e consequentemente a conversão alimentar. No entanto, os cordeiros Santa Inês apresentam medidas morfométricas de carcaça maiores.

Palavras-chave: Cenchrus ciliaris L. Seca. Longissimus dorsi área. Ruminante. Semiárido.

\section{Introduction}

The different vegetation typologies present in the semi-arid region of the Brazilian Northeast occur due to higher or lower edaphoclimatic aridity (soil and climate conditions), which in general, is associated with the coastal distance, altitude, geomorphology, relief desiccation level, slope and slope position relative to the wind (upwind and downwind), soil composition and depth and physical chemistry (BODNER; ROBLES, 2017; BRAND, 2017; CARRIÓN et al., 2017).

An increase in altitude leads to a reduction in temperature and, consequently, to an increase in precipitation and availability of water in soil, which is the main limiting factor of primary productivity in semi-arid regions. In Brazil, the semi-arid tropical zone comprises approximately $12 \%$ of its area, and corresponds to an exclusive Brazilian biome, locally known as Caatinga (PINHEIRO et al., 2013). Caatinga vegetation is the natural feed of goats and sheep (NYAMANGARA; NDLOVU, 1995; NUNES et al., 2016). According to Bandeira et al. (2017), Caatinga vegetation is mainly composed of trees, shrubs (including cactuses and bromeliads) and herbs (mainly annual grasses and dicotyledonous species). The carrying capacity of Caatinga vegetation is low because most of its forage is in the tree canopy beyond the reach of animals (SILVA et al., 2015). Proper management practices, such as thinning and lowering, to keep animal production and plant diversity at reasonable levels (PEREIRA FILHO et al., 2013) are needed to improve the carrying capacity of Caatinga vegetation for both sheep and goats (BANDEIRA et al., 2017). Vegetation enrichment is a possible manipulation technique that consists of controlling undesirable woody species to decrease the soil cover by shrubs and trees to approximately $15 \%$, followed by sowing grass that is adapted to the local soil and climate (SILVA et al., 2016; BANDEIRA et al., 2017). In the Caatinga region, buffel (Cenchrus ciliaris L.) grass is one of the most drought resistant and commonly used grass species in planted pastures. Although the selection capacity of goat kids and lambs depends on the botanical composition of the pasture, their forage preferences in the field are different: goats tend to browse leaves and fine stems of shrubs and trees, while sheep focus on herbs (PFISTER et al., 1988; ANIMUT; GOETSCH, 2008; OLIVEIRA et al., 2016). In addition, joint management of goat kids and lambs in the same system is often difficult because they are different species and should therefore be treated according to their individual growth requirements.

Thus, animal performance and carcass characteristics can be affected by the nutritional composition of the diet, which is different between goat kids and lambs. In addition, meat consumers demand carcasses with maximum muscle and minimal fat, which are usually more common in goat carcass. However, farmers prefer lamb meat because lambs have a greater slaughter weight and 
increased carcass yield (FERREIRA et al., 2016). This study compared the differences between the performance and carcass characteristics of goat kids and lambs finished in thinned Caatinga vegetation enriched with Cenchrus ciliaris L. grass.

\section{Materials and Methods}

\section{Location and ethical considerations}

This study was conducted at the Experimental Station at the Federal University of Campina Grande $\left(07^{\circ} 05^{\prime} 10^{\prime \prime} \mathrm{N}\right.$ and $\left.37^{\circ} 15^{\prime} 43^{\prime \prime} \mathrm{W}\right)$, Paraiba state, Brazil. The climate classification is BShw according to the Koppen classification: tropical semi-arid with a short moist season and rain falling in summer/autumn (January-May), concentrated in March and April. The dry season is as long as 8 months and normally begins in June and finishes in mid-January. The reported annual total rainfall ranges from $256.4 \mathrm{~mm}$ to $1365.7 \mathrm{~mm}$ and was $1395.9 \mathrm{~mm}$ during the time when the experiment was carried out. The annual mean, minimum and maximum temperatures for this period were $28^{\circ} \mathrm{C}$, $22^{\circ} \mathrm{C}$ and $35^{\circ} \mathrm{C}$, respectively, and the air moisture values were $68 \%, 65 \%$ and $71 \%$, respectively.

All protocols were conducted according to the Ethical Principles of Animal Experimentation adopted by the Animal Use Ethics Committee of Federal University of Campina Grande, Paraiba state, Brazil, Protocol 29/2008.

\section{Pasture}

The vegetation of the experimental site was in the initial phase of secondary succession and included herb, shrub and tree strata. The herb stratum included grass (Brachiaria plantaginea Panicum sp., Digitaria sp., Setaria sp. and Aristida setifolia $H-B-K$., as well as the introduced buffel grass) and dicotyledonous species (Hyptis suaveolens (I.)Poit, Phaseolus lathyroides L., Centrosema sp., Macroptilium martii, Sida cordifolia L. and
Stylozanthes sp.). Croton sonderianus Muell. Arg., Caesalpinia bracteosa Tul. and Combretum leprosum Mart. predominate in the shrub stratum, while Mimosa tenuiflora Willd. Poiret and Zizyphus joazeiro Mart. were the most numerous tree species.

The 2.4 ha experimental site was divided into four 0.6 ha paddocks. Two randomly chosen paddocks received six goat kids each, and the other two paddocks received six lambs each, equivalent to a continued grazing pressure of 10 animals/ha in each paddock. Grazing was allowed daily from 8:00 to $17: 00 \mathrm{~h}$ for a period sufficient for the animals to reach $30 \mathrm{~kg}$ of $\mathrm{BW}$ or for a 120-day period, whichever occurred first.

Selective thinning of Caatinga vegetation was performed in the experimental area by removing some of the undesirable tree species, especially Mimosa tenuiflora Willd Poiret and Croton sonderianus Muell. Arg., which suppress herbaceous forage production due to excessive shadowing. When tree coverage was reduced to $15 \%$ of the soil surface (PEREIRA FILHO et al., 2013), seeds of Cenchrus ciliaris L. was mixed with goat manure and sowed broadcast in uncultivated paddocks.

\section{Animals}

Twelve crossbred Boer $\times$ undefined breed goat kids and 12 Santa Inês lambs were used; all animals were identified by a colored necklace and averaged $20.7 \mathrm{~kg}$ of body weight and 110 days of age at the beginning of the experiment. Two goat kids and two lambs were randomly chosen from these animals to record fecal production. Forty-five days from the beginning of the experiment, four fistulated sheep and goats, two of each species, were allowed to browse in the experimental area. After a 14-day adaptation period, the ingested forage was sampled and animals were removed from the experimental area. Early in the adjustment period, animals were identified, weighed and wormed to control ecto- and endo-parasites. Goat kids and lambs stayed together 
every night in a pen and were provided water and a mineral mixture according to the requirements of each small ruminant species.

\section{Dry matter availability and chemical composition}

Dry matter availability ( $\mathrm{kg} / \mathrm{ha}$ ) from buffel grass, other grasses and dicotyledonous species were estimated separately after cutting them close to the soil at sampling points. A sampling point consisted of an area inside a $1.00 \mathrm{~m} \times 0.25 \mathrm{~m}$ iron frame that was randomly placed in the North-South and EastWest transects crossing the middle point of each lot according to Araújo Filho (1991). Sampling was performed at 20 sampling points of the paddock grazed by goat kids and 20 sampling points of the paddock grazed by lambs in each period of evaluation. The first evaluation was performed immediately before animals were allowed to graze (Table 1). Herb samples were collected from each lot, and biomasses from buffel grass, other grasses and dicotyledonous species were separated, weighted and analyzed according to the methods of the Association of Official Analytical Chemists (AOAC, 1990) to determine the levels of DM (method 967.03), ash (method 942.05), CP (method 981.10), EE (method 920.29) and acid-detergent fiber (method 913.18). The content of neutral detergent fiber (NDF) was determined according to Van Soest et al. (1991).

Table 1. Availability and chemical composition of herbaceous vegetation in lots before animals were allowed to graze.

\begin{tabular}{lcccccc}
\hline \multirow{2}{*}{\multicolumn{1}{c}{ Variables }} & \multicolumn{3}{c}{ Lots browsed by goats } & \multicolumn{3}{c}{ Lots browsed by sheep } \\
\cline { 2 - 7 } & $\begin{array}{c}\text { Buffe }^{\mathrm{a}} \\
\text { grass }\end{array}$ & $\begin{array}{c}\text { Other } \\
\text { Grasses }\end{array}$ & Dicot $^{\mathrm{b}}$ & $\begin{array}{c}\text { Buffel } \\
\text { grass }^{*}\end{array}$ & $\begin{array}{c}\text { Other } \\
\text { Grasses }\end{array}$ & Dicot $^{\mathrm{b}}$ \\
\hline Dry matter availability $\left(\mathrm{kg} \mathrm{ha}^{-1}\right)$ & 1388.1 & 201.2 & 1262.0 & 1332.3 & 505.6 & 1676.6 \\
Dry matter $\left(\mathrm{g} \mathrm{kg}^{-1}\right.$ as fed) & 388.5 & 376.5 & 276.1 & 404.9 & 393.8 & 294.5 \\
Ash $\left(\mathrm{g} \mathrm{kg}^{-1} \mathrm{DM}\right)$ & 113.3 & 78.9 & 99.7 & 119.6 & 94.6 & 89.0 \\
Organic matter $\left(\mathrm{g} \mathrm{kg}^{-1} \mathrm{DM}\right)$ & 893.1 & 929.1 & 918.9 & 905.3 & 914.1 & 927.1 \\
Crude protein $\left(\mathrm{g} \mathrm{kg}^{-1} \mathrm{DM}\right)$ & 41.2 & 64.3 & 82.3 & 43.2 & 42.8 & 79.3 \\
Neutral detergent fiber $\left(\mathrm{g} \mathrm{kg}^{-1} \mathrm{DM}\right)$ & 762.1 & 779.0 & 636.8 & 794.8 & 787.9 & 642.8 \\
Acid detergent fiber $\left(\mathrm{g} \mathrm{kg}^{-1} \mathrm{DM}\right)$ & 487.3 & 471.1 & 514.2 & 517.3 & 481.3 & 529.5 \\
\hline
\end{tabular}

${ }^{\mathrm{a} C e n c h r u s ~ c i l i a r i s ~ L . ~}$

${ }^{\mathrm{b} D i c o t y l e d o n s ~ s p e c i e s . ~}$

\section{Grass intake and digestibility}

Grass intake was determined according to the chemical composition of the extrusa (GOES et al., 2003) 60 days after the beginning of the experimental period. Four fistulated animals, two goat kids and two lambs with the same average body weight and age, remained in the same pickets as the other animals. The rumen content (extrusa) of the fistulated animals was removed before they entered the pasture area. The fistulated animals were allowed to browse; after $20 \mathrm{~min}$ in the field, the total content of rumen was collected, stored in an icerefrigerated container, and analyzed according to the methods of the AOAC (1990) to determine the nutrient concentrations and indicator in the forage (extrusa).

Feces production (FP) of the experimental animals was estimated with the use of the external indicator hydroxyphenyl propane (LIPE) (SALIBA et al., 2003). LIPE® (250 mg /day) was added directly to the rumen of each fistulated animal $(n=$ 4) for five days. Fecal samples were collected from four animals (the two heaviest and the two lightest animals) of each species. Feces samples were manually collected from the rectal ampoule of the animals on the third day. The fecal samples of each animal were homogenized, pre-dried, ground, stored in labeled glass containers, and analyzed by an infrared 
spectrophotometer (Perkin-Elmer ${ }^{\circledR}, \quad$ Überlingen, Germany). Fecal production was estimated to divide the quantity of administered LIPE in rumen $\times 100$ of the LIPE concentration in the feces.

To determine the internal indicator, indigestible neutral detergent fiber (iNDF), samples of fodder concentrates and feces were incubated in the rumen of four fistulated animals for $144 \mathrm{~h}$, and the residue was assumed to be indigestible. Dry matter intake (DMI) was estimated from fecal production and was verified with the use of LIPE $®$ as an external marker and indigestible neutral detergent fiber (iNDF) as an internal marker (FORBES, 1995).

The in vitro digestibility assay was performed according to the methodology of Tilley and Terry (1963). The ruminal contents were collected in the morning, transferred to preheated thermo-flasks $\left(39^{\circ} \mathrm{C}\right)$ and transported immediately to the laboratory, and the rumen fluid was filtered using a fine sieve. A mineral buffer solution was later added to the rumen fluid in a water bath maintained at $39^{\circ} \mathrm{C}$ with a continuous $\mathrm{CO}_{2}$ injection. The samples were placed in an incubator, under rotation, for $72 \mathrm{~h}$. Peptides were added to the incubators within $48 \mathrm{~h}$ to act as intermediate compounds for microorganisms.

\section{Performance and carcass traits}

Goat kids and lambs were individually weighed at the beginning and at the end of the experiment to determine the total weight gain (TWG) of lambs and their average daily gain (ADG). Feed conversion (feed:gain ratio) was determined using the average dry-weight intake of lambs fed the different diets divided by their average daily gain (ADG), which was calculated based on the difference between the initial and final BW of animals divided by the number of days in the trial period for each animal species. The values are expressed as $\mathrm{kg} \mathrm{kg}^{-1}$.

When the animals reached a mean of $30 \mathrm{~kg}$ of body weight $(\mathrm{BW})$, they were subjected to a $16-\mathrm{h}$ fasting period, weighed to determine the slaughter weight (SW), and then stunned using the appropriate equipment (Dal Pino, Santo André, SP, Brazil) that promoted electronarcosis (minimum current of 1.25 amperes). Then, animals were bled, skinned, and eviscerated. After skinning, gutting, and removing the head, feet and genitals, the hot carcass weight (HCW, kg) was obtained.

The gastrointestinal tract was removed, weighed and emptied to obtain the gastrointestinal content weight (GCW) and empty body weight (EBW) $(\mathrm{EBW}=$ slaughter weight $(\mathrm{SW})-$ minus $\mathrm{GCW}-$ minus the weight of the liquid content in bladder and gall bladder).

After the removal of the head and feet, the carcasses were cooled in cold storage for $24 \mathrm{~h}$ at $4^{\circ} \mathrm{C}$ and then weighed to determine the cold carcass weight (CCW kg). Using these data, the hot ( $\mathrm{HCY})$ and cold carcass yield (CCY) were calculated based on the carcass weight relative to the body weight at slaughter $\left(\mathrm{g} \mathrm{kg}^{-1}\right)$. The biological yield [TY $\left(\mathrm{g} \mathrm{kg}^{-1}\right)$ $=(\mathrm{HCW} / \mathrm{GC}) \times 100]$ was determined as described by Cartaxo et al. (2009). The subcutaneous fat thickness (SFT) was measured with a caliper and obtained at three-quarters of the distance from the medial side of the Longissimus lumborum muscle to its lateral side along the dorsum-lumbar line. Perirrenal fat was obtained after cooling and before the half-carcass was obtained.

The Longissimus dorsi area (LDA) was determined on the transversal section surface between the 12th and 13th ribs. A transparent PVC film sheet (Maxprint, SP, São Paulo, Brazil) and appropriate non-toxic pen model 4053 (Molin, SP, São Paulo, Brazil) were used to delimitate the LDA. Then, the transparent PVC film sheet was scanned (Hewlett-Packard Development Company, SP, São Paulo, Brazil) and the pixel area was converted to $\mathrm{cm}^{2}$ using the Quant software.

The carcass morphometric characteristics of goat kids and lambs were measured according to Yañez et al. (2004). The parameters measured included the carcass internal length (the distance between 
the anterior end of the pubic bone and middle point of the anterior end of the first rib), carcass external length (the distance between the cervico-thoracic joint and first inter-coccygeal joint), leg length (the distance between the greater trochanter of the femur and end of the tarsometatarsal joint), rump width (the distance between the femoral trochanters), chest width (the distance between the shoulders) and chest circumference (the perimeter measured behind the shoulders). The carcass compactness index $(\mathrm{CCI})$ was calculated by $\mathrm{CCI}=\mathrm{CCW} /$ carcass internal length.

\section{Statistical analysis}

The feed intake, animal performance and carcass characteristic data were analyzed according to a completely random design, with two treatments (goat kids and lambs) and twelve replications (animals). The initial body weight was used as a covariate to evaluate performance and the hot and cold carcass weights, but these weights were removed from the model as they were shown to have no significant effects. Statistical analyses were performed using the PROC ANOVA module of the SAS ${ }^{\circledR}$ (2003) statistical software program. The significance level was set at a probability of $5 \%(P \leq 0.05)$.

\section{Results}

Goat kids presented greater $(P<0.05)$ organic matter intake ( $\mathrm{g} \mathrm{day}^{-1} ; \mathrm{g} \mathrm{kg}^{-1}$ of BW and $\mathrm{g} \mathrm{kg}^{-0.75} \mathrm{day}^{-1}$ ) compared to lambs fed Caatinga vegetation enriched with Cenchrus ciliaris L. grass (Table 2). However, the intake $\left(\mathrm{g} \mathrm{day}^{-1}\right)$ of crude protein-CP $(P=0.297)$ and neutral detergent fiber-NDF $(P=0.294)$ was similar between the two species. The organic matter digestibility was greater $(P=0.033)$ in goat kids compared to that in lambs, with an average of 566 and $513 \mathrm{~g} \mathrm{~kg}^{-1}$ for goat kids and lambs, respectively. However, crude protein digestibility was similar $(P$ $=0.155)$ between goat kids and lambs. The total weight gain $(P=0.002)$ and average daily gain $(P=$ $0.043)$ were greater in goat kids than in lambs and, consequently, improved $(P=0.040)$ goat kids (5.78 $\mathrm{kg} \mathrm{kg}^{-1}$ ) feed conversion compared to that of lambs $\left(8.98 \mathrm{~kg} \mathrm{~kg}^{-1}\right)$.

The slaughtering weight was similar $(P>0.05)$ for both species (Table 3), which was a result of the chosen methodology in which animals were only slaughtered when they reached $30 \mathrm{~kg}$ of BW, which decreased to $27.4 \mathrm{~kg}$ (goat kids) and $28.7 \mathrm{~kg}$ (lambs) after a $16 \mathrm{~h}$ fasting period. The empty body $(P=$ $0.076)$, hot carcass $(P=0.082)$ and cold carcass $(P$ $=0.090)$ weights; cooling carcass loss $(P=0.297)$; biological yield $(P=0.111)$, hot carcass $(P=0.985)$ and cold carcass $(P=0.926)$ yields; subcutaneous fat thickness $(P=0.608)$; Longissimus dorsi area $(P=0.403)$; and pelvic fat $(P=0.062)$ were similar between goat kids and lambs grazing on Caatinga vegetation enriched with Cenchrus ciliaris L. Perirrenal fat was greater $(P=0.040)$ in goat kids compared to that in lambs.

Table 2. Comparison of the intake, digestibility and performance of crossbred goat kids (Boer $\times$ undefined breed) and Santa Ines lambs that finished grazing on Caatinga vegetation enriched with buffel (Cenchrus ciliaris L.) grass.

\begin{tabular}{lcccc}
\hline \multicolumn{1}{c}{ Variables } & Goat kids & Lambs & SEM $^{\mathrm{a}}$ & $P$-value \\
\hline Intake & & & & \\
Organic matter $\left(\mathrm{g} \mathrm{day}^{-1}\right)$ & $537.5^{\mathrm{A}}$ & $464.3^{\mathrm{B}}$ & 5.31 & 0.010 \\
Organic matter $\left(\mathrm{g} \mathrm{kg} \mathrm{BW}^{-0.75}\right.$ day $\left.^{-1}\right)$ & $52.8^{\mathrm{A}}$ & $39.7^{\mathrm{B}}$ & 2.39 & 0.018 \\
Organic matter $\left(\mathrm{g} \mathrm{kg}^{-1}\right.$ of BW) & $24.4^{\mathrm{A}}$ & $17.5^{\mathrm{B}}$ & 0.32 & 0.024 \\
Crude protein $\left(\mathrm{g} \mathrm{day}^{-1}\right)$ & 56.9 & 54.3 & 1.78 & 0.297 \\
Neutral detergent fiber $\left(\mathrm{g} \mathrm{day}^{-1}\right)$ & 435.9 & 416.3 & 4.92 & 0.294
\end{tabular}


continuation

Digestibility

Organic matter $\left(\mathrm{g} \mathrm{kg}^{-1}\right)$

$566^{\mathrm{A}}$

$513^{\text {B }}$

1.65

0.033

Crude protein $\left(\mathrm{g} \mathrm{kg}^{-1}\right)$

573

536

1.79

0.155

Performance

Initial weight $(\mathrm{kg})$

$\begin{array}{ll}20.7 & 20.7\end{array}$

Final weight $(\mathrm{kg})$

30.0

30.0

Experimental time (days)

83.0

117.0

Total gain $(\mathrm{kg})$

$7.69^{\mathrm{A}}$

$6.04^{\mathrm{B}}$

$93.0^{\mathrm{A}} \quad 51.8^{\mathrm{B}}$

Average daily gain $(\mathrm{g})$

$5.78^{\mathrm{B}}$

$8.98^{\mathrm{A}}$

$\begin{array}{cc}- & - \\ - & - \\ - & - \\ 0.59 & 0.002 \\ 4.92 & 0.043 \\ 1.69 & 0.040\end{array}$

${ }^{a} \mathrm{SEM}=$ Standard error of the mean.

${ }^{\mathrm{b}} P$-value $=$ Means for each variable followed by different letters are significant at 0.05 .

Table 3. Comparison between the Carcass traits of crossbred goat kids (Boer $\times$ undefined breed) and Santa Ines lambs that finished grazing on Caatinga vegetation enriched with buffel (Cenchrus ciliaris L.) grass.

\begin{tabular}{lcccc}
\hline \multicolumn{1}{c}{ Carcass traits } & Goat kids & Lambs & SEM $^{\mathrm{a}}$ & $P$-value \\
\hline Slaughtering weight $(\mathrm{kg})$ & 27.4 & 28.7 & 1.43 & 0.220 \\
Empty body weight $(\mathrm{kg})$ & 21.2 & 22.2 & 1.34 & 0.076 \\
Hot carcass weight $(\mathrm{kg})$ & 10.5 & 10.9 & 1.17 & 0.082 \\
Cold carcass weight $(\mathrm{kg})$ & 9.98 & 10.4 & 1.14 & 0.090 \\
Cooling carcass loss $\left(\mathrm{g} \mathrm{kg}^{-1}\right)$ & 45.5 & 44.0 & 8.12 & 0.297 \\
Biological yield $\left(\mathrm{g} \mathrm{kg}^{-1}\right)$ & 491 & 490 & 17.38 & 0.111 \\
Hot carcass yield $\left(\mathrm{g} \mathrm{kg}^{-1}\right)$ & 381 & 380 & 17.44 & 0.985 \\
Cold carcass yield $\left(\mathrm{g} \mathrm{kg}^{-1}\right)$ & 362 & 363 & 17.09 & 0.926 \\
Subcutaneous thickness fat $(\mathrm{mm})$ & 0.51 & 0.56 & 0.46 & 0.608 \\
Perirrenal fat (g) & $54.8^{\mathrm{A}}$ & $34.1^{\mathrm{B}}$ & 4.43 & 0.040 \\
Pelvic fat (g) & 3.78 & 3.60 & 1.91 & 0.062 \\
Longissimus dorsi area $\left(\mathrm{cm}^{2}\right)$ & 8.62 & 9.27 & 1.33 & 0.403 \\
\hline
\end{tabular}

${ }^{\text {a SEM }}=$ Standard error of the mean.

${ }^{\mathrm{b}} P$-value $=$ means for each variable followed by different letters are significant at 0.05 .

Most carcass measurements, such as the external $(P=0.038)$ and leg lengths $(P=0.049)$, chest $(P=$ $0.040)$ and rump $(P=0.042)$ widths, leg perimeter $(P=0.036)$ and chest circumference $(P=0.041)$ presented greater values for lambs compared to those for goat kids (Table 4). However, the carcass compactness index (CCI; $P=0.066)$, internal length $(P=0.506)$ and perimeter width $(P=0.148)$ were similar between goat kids and lambs.

Table 4. Morphometric carcass measurements of crossbred goat kids (Boer $\times$ undefined breed) and Santa Ines lambs that finished grazing on Caatinga vegetation enriched with buffel grass.

\begin{tabular}{lcccc}
\hline \multicolumn{1}{c}{ Morphometric measurements } & Goat kids & Lambs & SEM $^{\mathrm{a}}$ & P-value $^{\mathrm{b}}$ \\
\hline External length $(\mathrm{cm})$ & $50.8^{\mathrm{B}}$ & $54.7^{\mathrm{A}}$ & 1.44 & 0.038 \\
Internal length $(\mathrm{cm})$ & 57.9 & 58.3 & 1.31 & 0.506 \\
Leg length $(\mathrm{cm})$ & $36.0^{\mathrm{B}}$ & $38.5^{\mathrm{A}}$ & 1.35 & 0.049
\end{tabular}

continue 
continuation

\begin{tabular}{lcccc} 
Chest width $(\mathrm{cm})$ & $17.9^{\mathrm{B}}$ & $20.1^{\mathrm{A}}$ & 1.08 & 0.040 \\
Rump width $(\mathrm{cm})$ & $18.6^{\mathrm{B}}$ & $20.4^{\mathrm{A}}$ & 1.03 & 0.042 \\
Perimeter width $(\mathrm{cm})$ & 25.0 & 25.5 & 1.29 & 0.148 \\
Leg perimeter $(\mathrm{cm})$ & $29.0^{\mathrm{B}}$ & $33.8^{\mathrm{A}}$ & 1.68 & 0.036 \\
Chest circumference $(\mathrm{cm})$ & $51.8^{\mathrm{B}}$ & $56.2^{\mathrm{A}}$ & 1.39 & 0.041 \\
Carcass compactness index $\left(\mathrm{kg} \mathrm{cm}^{-1}\right)$ & 0.17 & 0.18 & 0.15 & 0.066 \\
\hline
\end{tabular}

${ }^{\mathrm{a}} \mathrm{SEM}=$ Standard error of the mean.

${ }^{\mathrm{b}} P$-value $=$ means for each variable followed by different letters are significant at 0.05 .

\section{Discussion}

According to the chemical composition of the selected diet, which was determined by collection of the rumen contents of goat kids $(241,95.0,787$ and $487 \mathrm{~g} \mathrm{~kg}^{-1}$ dry matter (DM), crude protein (CP), neutral detergent fiber (NDF) and acid detergent fiber (ADF), respectively) and lambs (278, 93.0, 776 and $431 \mathrm{~g} \mathrm{~kg}^{-1} \mathrm{DM}, \mathrm{CP}, \mathrm{NDF}$ and ADF of ingested feed, respectively), the forage quality remained great and positively affected body weight gain. In addition, the herb forage availability in Caatinga vegetation may have an effect on plant selection by animals (SANTOS et al., 2008; SILVA et al., 2015; BANDEIRA et al., 2017), and goat kids are more flexible than lambs regarding diet selection (PFISTER et al., 1988; McGREGOR, 2010). According to Araújo Filho (2013), the annual dry matter availability in unmanaged Caatinga is approximately $400 \mathrm{~kg} \mathrm{ha}^{-1}$, while the forage availability may increase to 2400 or $3600 \mathrm{~kg} \mathrm{ha}^{-1}$ by thinning the tree component or thinning the tree component plus enriching with drought-resistant grasses, respectively.

Comparing lambs and goat kids, kids selected more of the diet, meaning that they used the ingested feed more efficiently than lambs. Goats can change their diet according to forage availability, season, and plant diversity (ANIMUT et al., 2005) over such a wide range that Leite (2002) classified goats as having an opportunistic feeding behavior. Goats ingest forage from herbs and woody species (ANIMUT; GOETSCH, 2008; MORAIS et al., 2017) because they have the ability to stand on their hind-feet and reach higher shrubs and tree branches (SANON et al., 2007). In addition, goat kids can successfully select dicotyledonous herbs and improve their diet quality, especially on thinned Caatinga vegetation enriched with grasses (SANTOS et al., 2010; PEREIRA et al., 2013).

Araújo Filho et al. (1996) evaluated the botanical and chemical composition of the diet of sheep and goats in a native pasture in a semiarid region and observed that, at the beginning of the dry season, sheep preferred more grasses and less woody species than goats. However, this difference disappeared over time, which led them to classify sheep and goats as intermediate selectors of high food flexibility according to the season and availability of forage. In addition, the combination of goat and sheep can increase the grazing pressure on grasses in semi-arid regions (FORMIGA et al., 2012). Regarding the diets of goats and sheep in terms of the groups of plant species, the largest similarities occurred in the dry season, i.e., $95.8 \%$ for woody plants and $93.4 \%$ for grasses, while in the transition between rainy/dry seasons, the similarity was $75.9 \%$ for herbaceous dicotyledons (ARAÚJO et al., 1996). Thus, goats and sheep have a high degree of utilization of Caatinga vegetation.

Although Formiga et al. (2011), when comparing goat kids and lambs, observed no differences in digestibility values (643 and $627 \mathrm{~g}$ $\mathrm{kg}^{-1}$, respectively), the authors affirmed that goat kids quantitatively ingested more organic matter compared to lambs (437 vs. $331 \mathrm{~g} \mathrm{day}^{-1}, 47.2$ vs. $26.1 \mathrm{~g} \mathrm{~kg} \mathrm{BW}^{-0.75}$ and 22.5 vs. $11.2 \mathrm{~g} \mathrm{~kg}^{-1}$ of BW, 
respectively). The intake and digestibility of nutrients affect animal performance, which was corroborated by the digestibility data collected from the extrusa of lambs and goat kids in the present study. Andrade et al. (2007) reported an ADG of approximately $100 \mathrm{~g} \mathrm{day}^{-1}$ for Santa Ines lambs grazing on natural pastures enriched with buffel grass, which is almost two times the value observed for lambs in the present study. However, Araújo Filho (2013) reported an ADG of $47.1 \mathrm{~g}$ for goats and $34.0 \mathrm{~g}$ for lambs grazing together on Caatinga vegetation.

Most of the farmers in the semiarid region of Northeast Brazil raise goat kids and lambs that normally gain weight during the rainy season and lose weight during the long dry season (ARAÚJO FILHO, 2013; PEREIRA FILHO et al., 2013). According to Formiga et al. (2011), the use of grasses, such as buffel grass, to enrich thinned Caatinga vegetation increases the availability of DM and allows animals to select a diet containing a $90 \mathrm{~g} / \mathrm{kg}$ crude protein content and $580 \mathrm{~g} \mathrm{~kg}^{-1}$ of digestibility. Due to the selected diet, the weight loss during the dry season led to an ADG of 50 to $100 \mathrm{~g} \mathrm{day}^{-1}$, similar to that observed in the present study. These gains resulted in lambs with a $28 \mathrm{~kg}$ average live body weight, which is equivalent to 10 $\mathrm{kg}$ carcasses, at 210 days of age. According to Silva et al. (2010), these are the most accepted carcasses in the local market.

However, despite the greater performance of goat kids, there was a similarity between the hot ( $\mathrm{HCW}$ ) and cold (CCW) carcass weights and yields between species. This difference may have occurred due to the use of the slaughter weight (SW), by which animals are marketed, leading to consequently lower carcass yields. However, lambs had greater morphometric carcass measurements because carcass finishing is influenced by small ruminant species. According to reports by Cézar and Sousa (2010), one of the most striking differences among small ruminant species is that the subcutaneous adipose tissue in goat species is poorly developed or scarce, and almost all subcutaneous adipose tissue is deposited in body cavities. Goats, by their very nature, are sparsely covered by subcutaneous fat, although through breeding, some breeds have developed a reasonable amount of surface fat to the point that their carcasses can be typified as having medium finishing (CÉZAR; SOUSA, 2007). This observation explains the higher amount of perirrenal fat in goat kids compared to that in lambs.

The values of loss due to cooling, which affects the commercial yield of the carcass, were similar and can be considered good for goats and high for sheep considering that, in sheep, the values that are considered to be acceptable losses are from 3.0 to $4.0 \%$ (CORDÃO et al., 2102). The similarity between goat kids and lambs due to cooling weight losses may be associated with the low level of fat deposition in both lambs and goat kids. Dantas et al. (2008) reported an inverse relationship between the levels of covering fat due to cooling weight losses. High levels of weight loss due to cooling may affect the commercial carcass yield. In this study, high levels of losses in carcass weight due to cooling might be correlated with a small amount of covering fat, resulting from the qualitative limitations of the diet, as $\mathrm{OM}$ digestibility (566 and $513 \mathrm{~g} \mathrm{~kg}^{-1}$ for goat kids and lambs, respectively) should not limit fat deposition.

The subcutaneous fat thickness $(\mathrm{mm})$ results were similar in this study to those found in a study by Sousa et al. (2008), which evaluated carcasses by comparing the same genotypes of goats and sheep. According to the authors, goats and sheep of the animals were slaughtered with "lean" body condition, since the subcutaneous fat thickness was lower than $1.18 \mathrm{~mm}$ for a carcass considered "intermediate" and less than $2.0 \mathrm{~mm}$ even for a carcass considered "fat".

\section{Conclusion}

Goat kids (crossbred Boer $\times$ undefined breed) used Caatinga vegetation enriched with Cenchrus 
ciliaris L. more efficiently than Santa Inês lambs because goat kids presented a greater intake and digestibility of organic matter, increased total weight gain and ADG and, consequently, improved feeding conversion. However, Santa Inês lambs presented higher carcass morphometric values. In addition, although goat kids performed better under Caatinga biome conditions, the carcass finishing of goat kids and lambs can be influenced by several intrinsic and extrinsic factors, and further studies must be carried out to define the best conditions to obtain the ideal finish to produce the highest quality of meat of these species of ruminants.

\section{Acknowledgements}

The authors acknowledge the financial support by the National Council for Scientific and Technological Development (CNPq-Brazil).

\section{References}

ANDRADE, I. S.; SOUZA, B. B.; PEREIRA FILHO, J. M.; SILVA, A. M. A. Physiologic behavior and performance of lambs Santa Inês breed submitted to different types of environmental and supplementation in grazing. Ciência e Agrotecnologia, Lavras, v. 31, n. 2, p. 540-547, 2007.

ANIMUT, G.; GOETSCH, A. L. Co-grazing of sheep and goats: Benefits and constraints. Small Ruminant Research, Amsterdam, v. 77, n. 2-3, p. 127-145, 2008.

ANIMUT, G.; GOETSCH, A. L.; AIKEN, G. E.; PUCHALA, R.; DETWEILER, G.; KREHBIEL, C. R.; MERKEL, R. C.; SAHLU, T.; DAWSON, L. J.; JOHNSON, Z. B.; GIPSON, T. A. Performance and forage selectivity of sheep and goats co-grazing grass/ forb pastures at three stocking rates. Small Ruminant Research, Amsterdam, v. 59, n. 2-3, p. 203-215, 2005.

ASSOCIATION OF OFFICIAL ANALYTICAL CHEMISTS. - AOAC. Official methods of analysis. 15. ed. Washington: AOAC. 1990. 1117 p.

ARAÚJO FILHO, J. A. Manejo pastoril sustentável da caatinga. $22^{\text {th }}$ ed. Recife: Projeto Dom Helder Câmara, 2013.

ARAÚJO FILHO, J. A. Métodos de avaliação de pastagens nativas arbustivas e arbóreas. In: REUNIÃO
ANUAL DA SOCIEDADE BRASILEIRA DE ZOOTECNIA, 28., 1991, João Pessoa. Anais... João Pessoa: Imprenta, 1991. p. 37-47.

ARAÚJO FILHO, J. A.; SOUSA, F. B.; CARVALHO, F. C. Composição botânica e química da dieta de ovinos e caprinos em pastoreio combinado na região dos Inhamuns, Ceará. Revista Brasileira de Zootecnia, Viçosa, v. 25, n. 3, p. 383-395, 1996.

BANDEIRA, P. A. V.; PEREIRA FILHO, J. M. P.; SILVA, A. M. A.; CEZAR, M. F.; BAKKE, O. A.; SILVA, U. L.; BORBUREMA, J. B.; BEZERRA, L. R. Performance and carcass characteristics of lambs fed diets with increasing levels of Mimosa tenuiflora (Willd.) hay replacing Buffel grass hay. Tropical Animal Health and Production, Edinburgh, v. 49, n. 5, p. 1001-1007, 2017.

BODNER, G. S.; ROBLES, M. D. Enduring a decade of drought: Patterns and drivers of vegetationchange in a semi-arid grassland. Journal of Arid Environments, London, v. 136, n. 1, p. 1-14, 2017.

BRAND, M. A. Potential use of Caatinga forest biomass under sustainable management for energy generation. Ciência Florestal, Santa Maria, v. 27, n. 1, p. 117-127, 2017.

CARRIÓN, J. F.; GASTAUER, M.; MOTA, N. M.; MEIRA-NETO J. A. A. Facilitation as a driver of plant assemblages in Caatinga. Journal of Arid Environments, London, v. 142, n. 7, p. 50-58, 2017.

CARTAXO, F. Q.; CEZAR, M. F.; SOUSA, W. H.; GONZAGA NETO, S.; PEREIRA FILHO, J. M.; CUNHA, M. G. G. Quantitative traits of carcass from lambs finished in feedlot system and slaughtered at different body conditions. Revista Brasileira de Zootecnia, Viçosa, v. 38, n. 4, p. 697-704, 2009.

CÉZAR, M. F.; SOUSA, W. H. Carcaças ovinas e caprinas: obtenção, avaliação e classificação. Uberaba: Edit. Agropecuária Tropical, 2007. 231 p.

CÉZAR, M. F.; SOUSA, W. H. Proposta de avaliação e classificação de carcaças de ovinos deslanados e caprinos. Tecnologia \& Ciência Agropecuária, João Pessoa, v. 4, n. 4, p. 41-51, 2010.

CORDÃO, M. A.; CÉZAR, M. F.; SILVA, L. S.; BANDEIRA, P. A. V.; MORAES, F. F. A. de. Carcass acabament of sheep and goats - review bibliographic. ACSA - Agropecuária Científica no Semi-Árido, Patos, v. 8, n. 2, p. 16-23, 2012.

DANTAS, A. F.; PEREIRA FILHO, J. M.; SILVA, A. M. A.; SANTOS, E. M.; SOUSA, B. B.; CEZAR, M. F. Carcass characteristics of Santa Inês sheep 
finished in grazing and submitted to different levels of supplementation. Ciência e Agrotecnologia, Lavras, v. 32, n. 4, p. 1280-1286, 2008.

FERREIRA, R. C.; CÉZAR, M. F.; SOUSA, W. H. de; CUNHA, M. das G. G.; CORDÃO, M. A.; NÓBREGA, G. H. da. Biometrics, morphometry and regional composition of goat and sheep carcass from different genotypes. Revista Brasileira de Ciências Agrárias, Recife, v. 11, n. 3, p. 253-258, 2016.

FORBES, J. M. Voluntary food intake and diet selection in farm animals. Wallington: CAB International, 1995. $532 \mathrm{p}$.

FORMIGA, L. D. A. S.; PEREIRA FILHO, J. M.; OLIVEIRA, N. S.; SILVA, A. M. A.; CEZAR, M. F.; SOARES, D. C. Nutritive value of herbaceous vegetation of caatinga enriched and grazed by sheep and goats. Revista Brasileira de Saúde e Produção Animal, Salvador, v. 12, n. 2, p. 403-415, 2011.

FORMIGA, L. D. A. S.; PEREIRA FILHO, J. M.; SILVA, A. M. A.; OLIVEIRA, N. S.; SOARES, D. C.; BAKKE, O. A. Forage supply in thinned Caatinga enriched with buffel grass (Cenchrus ciliaris L.) grazed by goats and sheep. Acta Scientiarum Animal Science, Maringá, v. 34, n. 2, p. 189-195, 2012.

GOES, R. H. T. B.; MANCIO, A. B.; LANA, R. P.; VALADARES FILHO, S. C.; CECON, P. R.; QUEIROZ, A. C.; COSTA, R. M. Quality evaluation of the tanner grass (Brachiaria arrecta) pasture, by three different collection methods Revista Brasileira de Zootecnia, Viçosa, v. 32, n. 1, p. 64-69, 2003.

LEITE, E. R. Feeding management of grazing goats and sheep in northeastern Brazil. Ciência Animal, Sobral, v. 2, n. 2, p. 119-128. 2002.

McGREGOR, B. A. Influence of stocking rate and mixed grazing of Angora goats and Merino sheep on animal and pasture production in southern Australia. 1. Botanical composition, sward characteristics and availability of components of annual temperate pastures. Animal Production Science, Melbourne, v. 50, n. 2, p. 138-148, 2010.

MORAIS, J. S.; BEZERRA, L. R.; SILVA, A. M. A.; ARAÚJO, M. J.; OLIVEIRA, R. L.; EDVAN, R. L.; TORREÃO, J. N. C.; LANNA, D. P. D. Production, composition, fatty acid profile and sensory analysis of goat milk in goats fed buriti oil. Journal of Animal Science, Champaign, v. 95, n. 1, p. 395-406, 2017.

NUNES, A. T.; CABRAL, D. L. V.; AMORIM, E. L. C.; SANTOS, M. V. F. dos; ALBUQUERQUE, U. P. Plants used to feed ruminants in semi-arid Brazil: A study of nutritional composition guided by local ecological knowledge. Journal of Arid Environments, London, v. 135, n. 12, p. 96-103, 2016.

NYAMANGARA, M.; NDLOVU, L. Feeding behaviour, feed intake, chemical and botanical composition of the diet of indigenous goats raised on natural vegetation in a semi-arid region of Zimbabwe. The Journal Agricultural Science, London, v. 124, n. 3, p. 455-461, 1995.

OLIVEIRA, O. F. de.; SANTOS, M. V. F. dos.; CUNHA, M. V. da.; DUBEUX JÚNIOR, J. C. B.; MUIR, J. P.; MELLO, A. C. L. de; LIRA, M. A.; BARROS, G. F. N. P. de. Botanical composition of Caatinga rangeland and diets selected by grazing sheep. Tropical GrasslandsForrajes Tropicales, Cali, v. 4, n. 2, p. 71-81, 2016.

PEREIRA FILHO, J. M.; SILVA, A. M. A.; CEZAR, M. F. Management of the Caatinga for the production of goats and lambs. Revista Brasileira de Saúde e Produção Animal, Salvador, v. 14, n. 1, p. 77-90, 2013.

PFISTER, J. A.; MALECHEK, J. C.; BALPH, D. F. Foraging behaviour of goats and sheep in the Caatinga of Brazil. The Journal of Applied Ecology, Oxford, v. 25, n. 2, p. 379-388, 1988.

PINHEIRO, E. A. R.; COSTA, C. A. G.; ARAÚJO, J. C. de. Effective root depth of the Caatinga biome. Journal of Arid Environments, London, v. 89, n. 2, p. 1-4, 2013.

SALIBA, E. O. S.; FERREIRA, W. M.; PEREIRA, R. A. N. Lignin from Eucalyptus grandis as indicator for rabbits in digestibility trials. Tropical and Subtropical Agroecosystems, Yucatán, v. 3, n. 3, p. 1-43, 2003.

SANON, H. O.; KABORÉ-ZOUNGRANA, C.; LEDIN, I. Behaviour of goats, sheep and cattle and their selection of browse species on natural pasture in a Sahelian area. Small Ruminant Research, Amsterdam, v. 67, n. 1, p. 6474, 2007.

SANTOS, G. R. de A.; BATISTA, Â. M. V.; GUIM, A.; SANTOS, M. V. F. dos; SILVA, M. J. de A.; PEREIRA, V. L. A. Evaluation of botanical composition of sheep diet in Caatinga pasture. Revista Brasileira de Zootecnia, Viçosa, v. 37, n. 10, p. 1876-1883, 2008.

SANTOS, M. V. F.; LIRA, M. A.; DUBEUX JUNIOR, J. C. B.; GUIM, A.; MELLO, A. C. L.; CUNHA, M. V. Potential of Caatinga forage plants in ruminant feeding. Revista Brasileira de Zootecnia, Viçosa, v. 39, p. 204215, 2010. Suplemento Especial.

SILVA, D. C. da; GUIM, A.; SANTOS, G. R. de A.; SOUZA, E. J. de O.; URBANO, S. A.; MESQUITA, F. L. T. de; LAFAYETTE, E. A. Intake and digestibility of crossbred goats finished on caatinga grassland receiving feed supplementation during dry season. Revista Brasileira de Saúde e Produção Animal, Salvador, v. 17, n. 3, p. 484-496, 2016. 
SILVA, D. L. de S. da.; OLIVEIRA, K. P. de; AROEIRA, L. J. M.; CHAVES, D. F.; PONCIANO, M. F.; BRAGA, A. P.; LIMA JUNIOR, D. M. de. Chemical composition of Caatinga potential forages species. Tropical and Subtropical Agroecosystems, Yucatán, v. 18, n. 3, p. 267272, 2015.

SILVA, R. M.; PEREIRA FILHO, J. M.; SILVA, A. L. N.; CEZAR, M. F.; SILVA, A. M. A.; OLIVEIRA, N. S. The effect of supplementation on the tissue composition of the commercial cuts of cross-bred F1 (Boer $\times$ SPRD) finished in native pasture. Revista Brasileira de Zootecnia, Viçosa, v. 39, n. 6, p. 1353-1358, 2010.

SOUSA, W. H.; CARTAXO, F. Q.; CEZAR, M. F.; GONZAGA NETO, S.; CUNHA, M. G. G.; SANTOS, N.

M. Desempenho e características de carcaça de cordeiros terminados em confinamento com diferentes condições corporais. Revista Brasileira de Saúde Produção Animal, Salvador, v. 9, n. 4, p. 795-803, 2008.
STATISTICAL ANALYSIS SYSTEM - SAS. System for Windows, Release 9.1. Statistical Analysis System Institute. Inc., Cary, NC, USA, 2003.

TILLEY, J. M. A.; TERRY, R. A. A two stage technique for the "in vitro" digestion of forage crop. Grass and Forage Science, England, v. 18, n. 2, p. 104-111, 1963.

VAN SOEST, P. J.; ROBERTSON, J. B.; LEWIS, B. A. Methods for dietary fiber, neutral detergent fiber, and nonstarchpolyssacharides in relation to animal nutrition. Journal of Dairy Science, Madinson, v. 74, n. 10, p. 3583-3597, 1991.

YAÑEZ, E. A.; RESENDE, K. T.; FERREIRA, A. C. D.; MEDEIROS, A. N.; SILVA SOBRINHO, A. G.; PEREIRA FILHO, J. M.; TEIXEIRA, I. A. M. A.; ARTONI, S. M. B. Utilization of biometric measures for prediction of Saanen goats carcass traits. Revista Brasileira de Zootecnia, Viçosa, v. 33, n. 6, p. 15641572, 2004. 